\title{
"Good Works are Detrimental to Salvation": Amsdorf's Use of Luther's Words in Controversy
}

\author{
ROBERT KOLB
}

As the Protestant reformers died, their successors sorted and solidified the insights and institutions which constituted their legacy. This process involved numerous disputes, for among their disciples there had developed divergences of opinion regarding the proper interpretation of the reformers' message. Within German Lutheranism a number of such disputes were closely related to Luther's primary question: how does a person become righteous before God? Especially in Saxony graduates of the University of Wittenberg disputed questions which affected the understanding of the doctrine of justification through faith; the role of human works in the Christian life was the subject of sharp exchanges during one such dispute.

These disputes within German Lutheran ranks were largely ended through the adoption of the Formula of Concord of 1577. This document carefully presented what its formulators believed was Luther's true teaching on a number of controverted issues. It also condemned opposing doctrines, among them the proposition, "Good works are detrimental to salvation." 1 The dispute behind this condemnation not only illustrates the moods and concerns which dominated the Late Reformation in Saxony but also offers insights into Luther's early understanding of the way of salvation and his struggle against late medieval popular views of works - even though the Formula's rejection of the proposition, because of a suspicion of "Epicureanism," misrepresents the historical controversy and the original intent and understanding of the proposition. The claim, "good works are detrimental to salvation," was advanced by one of Luther's earliest converts, Nikolaus von Amsdorf, in the midst of the "Majoristic" controversy of the 1550s. The controversy, which took its name from Georg Major, a professor of theology at Wittenberg, concerned his proposition, "good works are necessary for salvation."2

Amsdorf was already teaching on the arts faculty at Wittenberg when Luther arrived there, and in 1516 he committed himself to Luther's developing cause. Luther's early struggles against medieval concepts of 
salvation and ecclesiastical authority had firmly shaped Amsdorf's new faith by the time he left Wittenberg in 1524 for Magdeburg. There, as ecclesiastical superintendent, he directed the Evangelical church during the years when the city was being won for Luther's Reformation. From 1542 to 1546 he served as Evangelical bishop of the diocese of NaumburgZeitz. Forced into retirement by the outbreak of the Smalcald War, Amsdorf spent the last two decades of his life embroiled in a series of controversies among Luther's followers over the proper interpretation of Luther's message. Most of these controversies evolved from an ecclesiastical compromise composed by members of what became known as the "Philippist" party within Saxon Lutheranism, led by Philip Melanchthon and several of his disciples. Their "Leipzig Interim," written in late 1548 at the behest of the new Saxon elector, Moritz, attempted to fend off Emperor Charles V and his troops, who wished to enforce the emperor's "Augsburg Interim" for the regulation of ecclesiastical life in the Protestant parts of Germany. The Leipzig Interim established ecclesiastical practices and doctrinal statements designed to make the emperor think that Moritz's regime was complying with imperial policy while actually preserving Lutheran teaching. The document was based upon the belief that compromises on indifferent matters, "adiaphora," were not of critical importance. Moritz's Interim aroused severe criticism outside his own lands, particularly in the city of Magdeburg, which was resisting Charles $\mathrm{V}$ and harbouring critics of the imperial Augsburg Interim. A bitter pamphlet war broke out between the Magdeburgers and Moritz's theologians at the Universities of Leipzig and Wittenberg. This dispute, called the "adiaphoristic" controversy, initiated a quarter century of controversy between the Philippists and Amsdorf"s party, the "Gnesio-Lutherans." While the Philippists were more conservative from a late medieval viewpoint on a number of theological issues and in various attitudes toward ecclesiastical practice, the Gnesio-Lutherans tended to interpret Luther's message more radically. Led by Matthias Flacius Illyricus, Nikolaus Gallus, and Amsdorf, this party attacked Moritz and his theologians, including Melanchthon, for their attempt to compromise with the papal party. They advanced the thesis which forms the basis of Formula of Concord article ten: "in time of persecution, nothing is adiaphora." 3

In one of his attacks on the Philippists in late 1551 Amsdorf singled out two former friends of his who remained at Wittenberg with Melanchthon, Johann Bugenhagen and Georg Major, for criticism; he assailed the Leipzig Interim's assertion that human virtues - among them faith, love, hope - are necessary for salvation. ${ }^{4}$

Georg Major and Amsdorf may have become good friends as early as the 1510s when Amsdorf taught and Major studied at Wittenberg. They 
certainly were well acquainted while Major taught in Magdeburg under Amsdorf's superintendency, 1529-1537. Their friendship had dissolved rather slowly under the stresses of controversy over the Interims, but Amsdorf's published criticism of Major's role in the adiaphoristic dispute set the scene for a prolonged controversy between them. ${ }^{5}$ For Major replied in his own defense and stated in passing, "I have previously taught and still teach and want to teach my whole life that good works are necessary for salvation, and I say openly and with plain words that no one will be saved through evil works and no one will be saved without good works." He called those who teach otherwise accursed. ${ }^{6}$

Major apparently did not realize the impact which his espousal of the proposition, "good works are necessary for salvation," would have on Amsdorf. He should have, for he had arrived in Magdeburg toward the end of a bitter fight between that city's Roman party and its Evangelical superintendent, Amsdorf. The cathedral canons there had attacked Amsdorf on the issue of good works, among others, and had tried to snuff out the infant Evangelical movement as they condemned Amsdorf for denying that good works are necessary for salvation. ${ }^{7}$

Amsdorf attacked Major's proposition, "good works are necessary for salvation," because, he argued, it could not be understood in any other way except that good works earn salvation for those who do them. Major disavowed that interpretation repeatedly throughout the next few years, but the several interpretations which he offered for his proposition did not allay Amsdorf's fears that common people, steeped in medieval concepts of works-righteousness, would not understand Major's glosses. In spite of Major's explanations Amsdorf and his friends remained convinced that Major's statements were suggesting that human actions do play some role in the salvation of the believer. ${ }^{8}$ Several colleagues joined Amsdorf in attacking Major and his friend, Justus Menius, who attempted to reinterpret Major's proposition while maintaining a strong opposition to antinomianism, the view that the law plays no role in the life of the Christian. ${ }^{9}$ During the 1550s and 1560s the dispute simmered as it went through several stages, including Amsdorf's attempt to clarify the matter with his proposition, "good works are detrimental to salvation."

Amsdorf and Major were never able to come to an agreement for a number of reasons. The charged ecclesiastical-political situation in Saxony during the 1550s and the growing personal bitterness between colleagues of the two prevented reconciliation. Furthermore, they differed in background, experience, and theological orientation. Amsdorf had shared Luther's earliest struggles against medieval concepts of salvation; as a young student he had received the same scholastic instruction which Luther had, and he never stopped reacting against it 
once Luther had transformed his thought. Major had imbibed the humanistic concerns of Melanchthon as he learned Luther's theology. $\mathrm{He}$ had served as a member of the electoral Saxon consistory and thus developed a concern for public order and morality. Amsdorf's experiences at Luther's side in Wittenberg and his later tribulations with the cathedral canons in Magdeburg had made his theology basically theocentric, reacting against the anthropocentrism of medieval popular belief. Major, on the other hand, shared Melanchthon's fear of libertinism and reacted with his preceptor against ethical indifference by attempting to develop effective ways of cultivating Christian living among first and second generation Lutherans. Finally, both Major and Amsdorf refused to recognize that they were using different definitions of the fundamental terms of their dispute, for example, of the word "salvation." Major defined salvation as the state in which the justified believer lives; Amsdorf believed that salvation meant the dynamic action of God which frees sinners from guilt and ensures them life with God forever.

That definition determined Amsdorf"s counter-proposition, "good works are detrimental to salvation." In 1557, in an introduction to Luther's sermons on John 18-20, Amsdorf wrote that Luther would surely have condemned Major and his followers, for Luther had written "everywhere and particularly in [his lectures on] Galatians, that good works are not only not necessary but even detrimental to salvation." $\mathrm{He}$ continued with the words he claimed to be citing from Luther:

Teaching and stressing works as necessary for salvation does more and greater harm than human reason can ever grasp or understand. For not only is the recognition of grace obscured through it, but Christ with all his benefits is thereby torn away and the whole gospel. . . is perverted. ${ }^{10}$

Scholars have puzzled over the source of Amsdorf's citation and have been unable to find these words in this form in Luther. ${ }^{11}$ However, the key elements of this quotation are to be found in Luther's discussion of Galatians 1, 6-7 in his Commentary on Galatians, based on his lectures of 1531 , first published in 1535. There Luther spoke of false prophets who taught "that in addition to faith in Christ the works of the law of God were also necessary for salvation." Several paragraphs later he stated,

It seems to be a trivial matter to teach the law and affirm works, but this does more damage than human reason can imagine. Not only does it mar and obscure the knowledge of grace, but it also removes Christ and all his blessings, and it completely overthrows the gospel....12

This is indeed the source of Amsdorf's citation.

Amsdorf always intended his proposition to be understood in the same sense in which Luther's discussion in his Galatians commentary was meant: reliance on good works prevents the sinner from trusting in 
the only source of salvation, God's grace in Jesus Christ. During the period in which Amsdorf and Luther worked together in Wittenberg, Luther had occasionally referred to the detrimental nature of good works whenever they are brought into the discussion of justification or salvation. In 1516 he had stated in a sermon that, for the person who has not been perfectly mortified, virtues and good works are more detrimental than sins; in the early 1520 s a number of his tracts or sermons referred to the detrimental nature of human works in regard to justification or salvation. He specifically applied the words "detrimental to salvation" to human works in certain cases. ${ }^{13}$

Amsdorf, in his first published work, A Christian Meditation on How to Pray the Our Father, Drawn from the Sermons of Doctor Martin Luther, printed in 1519, repeated these words which he had learned from Luther. In this tract he referred to the quality of his works, not just to trust in them, but by using the concept of the detrimental nature of human works he destroyed any possible basis for salvation in human moral conduct. God's grace is completely responsible for salvation since even the best of human actions are worthy in his sight only because he accepts them in his mercy apart from their own intrinsic worth. In prayer form Amsdorf wrote,

I am so sick, so poor, so wretched, so wounded - yes, half dead - that even the good work which I perform is not good for me but rather detrimental and damning. You will accept it only out of your tender, pure mercy, completely without any merit of my own, by grace. ${ }^{14}$

This attitude still determined his view of good works nearly four decades later.

Because he believed he was simply repeating Luther's own position, Amsdorf probably did not anticipate any criticism of his proposition, "good works are detrimental to salvation," when he published it in 1557. He received surprisingly little criticism, considering the atmosphere of antagonism and animosity which existed and the fact that his proposition was so obviously and easily open to misinterpretation. A few critics protested his position inside the church of ducal Saxony, the principality where the aging Amsdorf exercised considerable, though informal, authority. Amsdorf had recently engaged in dispute with certain members of the theological faculty at the ducal Saxon University of Jena and the ecclesiastical superintendent in Jena, Andreas Hügel. Amsdorf mentioned only Hügel in his rejoinder to local critics; even Hügel's name was disguised under a pun, "Master Klügel," a play on the pastor's name and the German word for "clever." 15

From outside ducal Saxony came some public disapproval of Amsdorf's proposition, for example, in Georg Major's Confession on the Article of 
Justification, published in 1558. Major regretted the encouragement that those who impiously write that good works are detrimental to salvation were giving to those antinomians who were arguing that the law has nothing to say to the Christian. ${ }^{16}$ Major was echoing Melanchthon's judgement, recorded in an unpublished memorandum on religious disputes prepared for Elector August of Saxony in December 1557. Melanchthon condemned the proposition, "good works are detrimental to salvation," as coarse antinomianism. ${ }^{17}$

Melanchthon and his colleagues did not launch a wide-spread attack on Amsdorf's proposition, however. The sniping between Amsdorf and his opponents did produce one tract exclusively dedicated to discussing the detrimental nature of good works for salvation - from Amsdorf himself. That tract appeared in 1559 under the title That the Proposition "Good Works are Detrimental to Salvation" is a Correct, True Christian Proposition, Taught and Preached by Saints Paul and Luther. ${ }^{18}$ Although Amsdorf attacked Major's critique of his proposition, issued the previous year in his Confession, censure from those he counted as friends actually prompted his writing this tract. Internal evidence points to Hügel as the provocateur $^{19}$ though comrades on the university faculty, particularly Viktorin Strigel, probably supported his criticism of Amsdorf. There is absolutely no basis for the suggestion that Amsdorf may have been reacting to criticism from his close friends, Matthias Flacius Illyricus and Johann Wigand, in this tract. ${ }^{20}$

Amsdorf began by making his view of good works clear: "good works are not necessary for salvation, but nonetheless they certainly are necessary for the new life of a Christian as signs, witnesses, and fruits of faith." 21 However, the wisdom of this world misleads people into believing that good works merit salvation, Amsdorf observed. Luther had written repeatedly against the false teaching of the "sophists" who taught that the man "who does what is in him" merits grace. This was a reference to the understanding of salvation taught by the Tübingen theologian, Gabriel Biel (1420-1495), whose thought dominated the instruction given Luther and Amsdorf as they had studied at the university. Biel was a butt of Amsdorf"s attacks on scholastic theology. ${ }^{22}$ Amsdorf unfairly implied that the "Majorists" were advancing a view of salvation similar to Biel's. He intended to take up the cudgel against that view by advancing the same proposition which Luther had used against Biel, "good works are detrimental to salvation."

In his tract Amsdorf did not merely quote Luther in defense of these words. That the proposition had firm scriptural support, Amsdorf was convinced. The prophets had taught that the good works of the Jews, such as sacrificing and incense, were sins and idolatry (he seems to have cited Isaiah 1, 11-13 at this point), and Paul wrote that "all who rely on 
the works of the law are under a curse" (Gal. 3, 10). ${ }^{23}$ Elsewhere Amsdorf cited Philippians 3, 6-7 in defense of his proposition; there Paul confessed that his blameless righteousness under the law was a "detriment" to him, according to the Vulgate, which Amsdorf cited. ${ }^{24}$

Amsdorf's view of the role which good works play in salvation was based on his conviction that the best of human works are sinful. Outside of grace no one, no human work, is good in God's sight. ${ }^{25}$ They are imperfect and impure and thus fall short of the demands of God's judgement. The works which Christian faith produces are also incomplete, but God graciously accepts them for Christ's sake on account of faith. Another of his comments illustrates Amsdorf's understanding of the continuing role of sin in the Christian's life. Because sin is not eradicated from the believer's life, it continues to plague him. The believing heart, which is producing fruits of the Spirit, does fall into sin. But when the pious falter, they quickly turn away from their sin. A spark of faith remains in the believer; he holds to the Word as he lives in hope and waits for the help which is certain to come to those who believe. ${ }^{26}$

By pointing out that good works are detrimental to salvation, he was not encouraging Epicureanism, however, Amsdorf insisted. For he was not thereby teaching that the fruits of faith are either unnecessary or incidental to the Christian life. Good works must result from faith and rebirth, for the new life created by faith is the beginning of eternal life itself. While the believer is given new life because of faith, not at all because of works, as a new creature and child of God he is capable of performing good works and serving God in holiness and righteousness. As long as faith exists, it produces good works. These works do not preserve or retain the salvation or righteousness which God has given; that takes place only through faith. Likewise, it is not some sinful action which causes the loss of righteousness and salvation; unbelief has destroyed that righteousness before the outward act of sin is committed. This position, too, repeats a concept which Luther had expressed while Amsdorf was still his colleague at Wittenberg. ${ }^{27}$ At the same point in this tract Amsdorf also made use of an illustration which he had learned from Luther forty years earlier: the believer is like a good tree which produces good fruit. The tree must first be good before it can produce good fruit. The good fruit does not make the tree good, but rather the tree produces fruit according to its nature. ${ }^{28}$ Amsdorf was concerned that Christians live a holy life; he was not an antinomian. ${ }^{29} \mathrm{He}$ was even more concerned that Christians not think that their own deeds could contribute to their own salvation or ensure the retention of God's favor. Because he believed that the popular definition of good works equated that term with meritorious human action in the process of salvation, he was confident that his proposition stated a Biblical principle clearly. 
He was obviously mistaken about its clarity, but the fact that his tract did not elicit more criticism indicates that even his foes recognized the intent of his proposition. His opponents shared his commitment to Luther's principles; on the other hand, they feared that words which could be construed as antinomian would create libertinism and public disorder. Furthermore, they were not above using such an ambiguous proposition for their own polemical purposes. However, they did not take issue with his contention that good works play no part whatsoever in bringing about the justification of the sinner.

The Philippist friends of Major occasionally alluded to Amsdorf's proposition in broadsides aimed at the followers of Flacius, usually without mentioning the name of the aging bishop, Luther's close friend. Major himself again criticized those who teach that good works are detrimental to salvation in the preface to his postil, or sermon book, on the epistle lessons for the Sundays of the church year, published in 1562. There he commented on the madness which advanced that idea and the opinions which he unfairly associated with it, for example, regarding the performance of good works as an indifferent matter or teaching that good works may or may not be performed as the Christian wishes. Amsdorf prepared a reply to Major's attack on "the Flacianists"; it remained in manuscript. In it he reiterated that good works cannot merit salvation and therefore are detrimental to those who want to rely on them to be saved. He appealed again to Paul and Luther in defense of his concept, and he heatedly denied the implications which Major had drawn from his proposition. ${ }^{30}$

In the same year, 1562, Amsdorf's assertion of the detrimental nature of good works in the discussion of justification also elicited comment by the Roman Catholic who had succeeded him as bishop of Naumburg after the Smalcald War, Julius von Pflug. Alongside his rejection of the belief that in and of themselves the sinner's good works are mortally sinful, Pflug condemned the view that good works are detrimental to salvation, in a public appeal for the support of the Roman faith in his largely Evangelical diocese. Cyriakus Spangenberg, a younger GnesioLutheran admirer of Amsdorf, published a critique of Pflug's tract, and in it he defended Luther and Amsdorf, explaining their views of good works in the context of their understanding of justification by grace through faith in Christ. ${ }^{31}$

The most extensive public attack on Amsdorf's proposition also appeared in 1562 in a pseudonymous tract issued by another Evangelical. Occasioned in part by Amsdorf's tract of the same year against the monastic canonical hours (a system for daily worship), this attack referred to Amsdorf by name - as a "madman who never could do anything like a rational being, as Philip Melanchthon used to say about him." Unjustly 
but understandably the author, probably writing from one of the strongholds of Amsdorf's foes, Leipzig or Wittenberg, accused him of trying to plant poisonous trees which would produce hellish fruits instead of fruits of faith and the Holy Spirit. He suggested that the devil was using Amsdorf as his instrument to lead people into the sins of the flesh and expressed his fear that Amsdorf's raving and raging would incite the common people to a new outbreak of revolt and bloodshed. The tract overlooked Amsdorf's claim to be reproducing Luther's thought completely as it simply dismissed his proposition as devilish and new, heresy which had never been heard of before - comparable to the fleshly heresies of Simon Magus, Basilides, and Eunomius. The author himself confessed that sinners are justified alone by God's grace through faith in Christ, and he went on to insist that the justified person is sanctified. The believer produces good works which are not only not detrimental to salvation but are good in themselves and will receive temporal and eternal rewards. ${ }^{32}$ With that conclusion, that believers' good works are good in themselves, Amsdorf would have disagreed, for that would imply that they are good apart from Christ. Amsdorf certainly would also have objected to the polemical misrepresentation of his position. Apparently, however, he did not rise to the challenge of this brief attack as his life ebbed.

Amsdorf's friends did not publicly support his proposition in the years around 1559; they avoided using it. Johann Wigand, a Magdeburg pastor who joined the Jena faculty in 1560, did defend it in correspondence, however. Writing a reply to a printed criticism by Hieronymus Weller, a superintendent in Saxon Freiburg, Wigand argued that in discussing justification it ought to be said that it can be only detrimental for a sinner to bring his own good works before God's judgement. To deny that is to minimize the horrible nature of sin. To say that good works are detrimental exalts Christ's merit; it denies the children of this world a false sense of security. Wigand recognized that good works are a necessary part of the Christian life, but he stressed the importance of making it clear that they must be excluded from justification. ${ }^{33}$

Amsdorf had cultivated no special disciples of his own, and so he left no one with an interest in defending his memory or his words. He had even alienated a group of his closest associates, several pastors in Magdeburg, in 1563, by objecting to their independent stance over against his old friends on the Magdeburg city council. ${ }^{34}$ At best Amsdorf's colleagues probably hoped that his unfortunate phrase would disappear from public scrutiny and memory.

It did not, however. The issue of good works was discussed in great detail at the Altenburg Colloquy, which took place between October 1568 and March 1569 in a futile attempt to reconcile Gnesio-Lutherans 
and Philippists. At Altenburg the Philippist delegation from electoral Saxony criticized the view that good works are detrimental to salvation. In reply the Gnesio-Lutheran theologians from the University of Jena, led by Wigand himself, quoted Amsdorf's manuscript criticism of Major's postil preface to explain that his proposition was correct and Biblical. They also cited passages from Luther which expressed this concept. ${ }^{35}$

At this same time Amsdorf's proposition commanded the attention of other German Lutheran theologians who were not directly involved in the party strife between the Gnesio-Lutherans and the Philippists. One was Martin Chemnitz, a student of Melanchthon, a close friend of members of both parties; he remained outside much of the exchange between them though his thought resembles that of the Gnesio-Lutherans at many points. ${ }^{36}$ In drafting a constitution for the Evangelical churches in the dukedom of Braunschweig-Wolfenbüttel in 1569, Chemnitz felt it necessary to warn against the concept that good works are detrimental to salvation. He did not mention Amsdorf's name; he did concede that those who believe that good works merit salvation are Pharisees and that Paul calls good works so understood detrimental in Philippians 3, 8. But Chemnitz then stressed that this concession in no way implies that the Christian ought not do good. He insisted on the teaching of the Augsburg Confession and its Apology that good works are necessary and that they certainly and necessarily result from faith. ${ }^{37}$

Chemnitz's friend, Jakob Andreae, called from the University of Tübingen to work with Chemnitz in the first Evangelical visitation of Braunschweig-Wolfenbüttel in 1568, agreed with this rejection of Amsdorf's proposition. Andreae initiated his second campaign to bring feuding Lutherans into harmony with his Six Christian Sermons on the Divisions among the Theologians of the Augsburg Confession, published in 1573. This book treated ten controversies among Lutherans, including that over good works. Andreae censured Major's proposition, "good works are necessary for salvation," but he believed that the "Epicurean" implications of saying that "good works are detrimental to salvation" posed as great a danger as did the encouragement toward dependence on good works for salvation possibly given by Major's proposition. Andreae identified Amsdorf as the author of the former proposition in a marginal note, printed alongside his rather fairly stated summary of Amsdorf's view. ${ }^{38}$

Four years later, as representatives of a number of German Lutheran churches were composing a formula for harmony among their churches, Andreae was called upon to summarize the position taken in the basic document which these formulators had produced. In the "Epitome" of this Formula of Concord he wrote, "we also reject and condemn as offensive and subversive of Christian discipline that bald statement that 
good works are detrimental to salvation." Andreae's concern here was the same as that which had motivated him in his Six Christian Sermons: "such an Epicurean dream concerning faith can damn people as much as a papistic and Pharisaic confidence in one's own works and merit." The longer "Solid Declaration" of the Formula of Concord, which Andreae was summarizing in his Epitome, presents a more detailed discussion of Amsdorf's proposition. Chemnitz was responsible for this section of the Solid Declaration, a document constructed by a committee of which Andreae and four others were also members. They affirmed the point which Amsdorf had intended to make with his proposition; at the same time they rejected the use of the proposition "without any qualifications." "Without explanation it is false and offensive, might weaken discipline and decency, and might introduce and confirm a wicked, wild, complacent, and Epicurean way of life." On the other hand, the formulators also confessed that good works are useless and harmful if they impede reliance on God's grace. They condemned drawing good works into the article of justification, attempting to find righteousness in God's sight or assurance of salvation in one's own good works. ${ }^{39}$ Had Amsdorf lived until 1577, he could have joined in the Formula's rejection of any suggestion that good works merit God's grace and save sinners even though he would have been angered by its rejection of his proposition, "good works are detrimental to salvation."

There were indeed a few theologians within German Lutheranism who did voice disgust with the Formula's rejection of Amsdorf's proposition in the period immediately after its composition. There were followers of Matthias Flacius who defended his understanding of original sin as the formal substance of the human creature after the fall. In their critiques of the Formula these "Flacianer" addressed above all its first article, which condemned Flacius' definition of original sin. But in addition Andreas Lange argued that the detrimental nature of good works is taught by Paul in Galatians 5 and Philippians 3 as well as by Luther. Cyriakus Spangenberg came once again to Amsdorf's defense; he condemned Andreae for misrepresenting Amsdorf's view in a sermonic defense of the Formula, and he set forth Amsdorf's intention in propounding the detrimental nature of good works. ${ }^{40}$ However, the voices of Spangenberg and Lange found no echo in the age of Lutheran Orthodoxy. Their plea for a proper understanding of Amsdorf's proposition went ignored. The theologians of the seventeenth and subsequent centuries regarded Amsdorf"s assertion "good works are detrimental to salvation" as a strange misstatement and misunderstanding of Luther's position and Biblical teaching.

Amsdorf, of course, believed that his proposition could not be misunderstood because of the predominance of the popular late medieval 
definition of good works as deeds which merit salvation. The formulators rejected so narrow a definition for the term. They ignored Amsdorf's citation of Luther and his affirmation of the necessity of the fruits of faith. For they were living in a situation which was quite different from that in which Luther had first formulated the concept of the detrimental nature of good works. By the 1570s two generations of German Evangelicals had grown up under the guidance of Lutheran pastors and teachers who had tried systematically and thoroughly to root out popular medieval concepts of salvation. The theologians who composed the Formula of Concord, as members of their princes' staffs, shared a public official's concern for public order as well as a theologian's concern for the Christian life. Indeed, they were also anxious to guard against doctrines which would weaken their parishioners' faith in Christ alone, in God's grace as the only cause of salvation. However, they believed that the dramatic language which Amsdorf had learned from Luther for combat against popular medieval concepts of works-righteousness was more confusing than helpful. Therefore, they rejected his terminology.

Amsdorf had simply wanted to defend Luther's understanding of justification without making any concession to antinomianism. He was wary of any words which seemed to revive the medieval popular belief in the efficacy of good works in saving sinners. He believed that he could do that by using a phrase which Luther had used in the early years of the Reformation when they were colleagues at Wittenberg. His antagonists disagreed with him, for they feared that these words might well lead parishioners astray, into a lax or libertine way of life. Like most controversies among Luther's heirs in the Late Reformation period, the clash over Amsdorf's proposition, "good works are detrimental to salvation," was a dispute arising out of pastoral issues, and thus it demonstrates that in the changing ecclesiastical situation of the second half of the sixteenth century Luther's prime concern, sensitivity to the spiritual needs of his people, continued to shape the thought and actions of his heirs.

\section{Concordia College - Saint Paul}

\section{Notes}

1 Die Bekenntnisschriften der evangelisch-lutherischen Kirche, 6. ed. (Göttingen: Vandenhoeck \& Ruprecht, 1967), Formula of Concord, Epitome IV, 17-18, p. 789; Solid Declaration IV, 37-40, pp. 949-50; The Book of Concord, ed. Theodore G. Tappert (Philadelphia: Muhlenberg, 1959), FC, Ep, p. 477; SD, pp. 557-58.

2 On the Majoristic controversy, along with standard histories of dogma and treatments of the Lutheran confessions, see Ragnar Bring, Das Verhältnis von Glauben und Werken in der lutherischen Theologie (Munich: Kaiser, 1955), pp. 75-106; Luther D. Peterson, "The Philippist Theologians and the Interims of 1548: Soteriological, Ecclesiastical, and Liturgical Compromises and Controversies within German Lutheranism," Ph.D. dissertation (University 
of Wisconsin-Madison, 1974), pp. 215-311; my Nikolaus von Amsdorf (1483-1565), Popular Polemics in the Preservation of Luther's Legacy (Nieuwkoop: De Graaf, 1978), pp. 123-80; and my "Georg Major as Controversialist: Polemics in the Late Reformation," Church History, 45 (1976), 455-68.

3 FC X, esp. Ep X, 6; SD X, 10-25: Bekenntnisschriften, pp. 815, 1057-62; Book of Concord, pp. 493, 612-15. On this controversy, see Peterson, pp. 113-214, and Amsdorf, pp. 69-122. On the two parties which arose out of this controversy, see my "Dynamics of Party Conflict in the Saxon Late Reformation, Gnesio-Lutherans vs. Philippists," The Journal of Modern History 49, 3 (1977), D1289-1305.

4 The text of the Leipzig Interim is printed in Philip Melanchthon's Opera, Corpus Reformatorum, eds. C.G. Bretschneider and H.E. Bindseil (Halle: Schwetschke, 1834-1860), henceforth abbreviated $C R$; see VII, 63.

5 Das Doctor Pomer vnd Doctor Maior mit iren Adiaphoristen ergernis vnnd zurtrennung angericht Vnnd den Kirchen Christi vnüberwintlichen schaden gethan haben (Magdeburg, 1551).

6 Auff des Ehrenwirdigen Herren Niclas vom Ambsdorff schrifft so jtzundt neulich Mense Nouembri Anno 1551, wider Georgen Maior öffentlich im Druck ausgegangen. Antwort (Wittenberg, 1552), lvs. Cv-Cijr.

7 Amsdorf's most detailed presentation of his position in his dispute with the Magdeburg Roman Catholic party came in his Das die werck nicht rechtfertigen - sondern der glaub allein. Widder die Thumprediger zu Magdeburg (Magdeburg, 1528); see Hans Stille, Nikolaus von Amsdorf. Sein Leben bis zu seiner Einweisung als Bischof in Naumburg (1483-1542) (Zeulenroda: Sporn, 1937), pp. 61-70, and my Amsdorf, pp. 39-40.

8 A survey of literature written in this controversy is given in my "Georg Major as Controversialist."

9 On Menius, see Alvin H. Horst, "The Theology of Justus Menius," Th.D. dissertation (Concordia Seminary, St. Louis, 1973), pp. 239-67.

10 Das achtzehend vnd neunzehend Capitel vnd ein Stuck aus dem zwentzigsten S. Johannis von dem Leiden Sterben vnd Aufferstehung vnsers Herrn Jhesu Christi. Gepredigt vnd ausgelegt durch Doc. Mart. Luth. Anno M.D. XXVIII. vnd XXIX (Jena, 1557), printed in D. Martin Luthers Werke (Weimar: Böhlau, 1883- ) [henceforth abbreviated WA], 28,765-67. Amsdorf wrote, "Denn Lutherus seliger und heiliger gedechtnis der schreibet allenthalben und sonderlich in Galatis, Das die guten werck nicht allein nicht nôtig, sondern auch zur seligkeit schedlich sind: Denn so lauten seine wort: Wenn mans in grund und im liecht eben besihet, So ists gewis und findet sich also, das solch leren und treiben auff die werck als notig zur seligkeit mehr und grossern schaden thut, denn kein menschliche Vernunfft imermehr begreiffen oder verstehen kan. Denn es wird nicht allein das erkentnis der Gnaden dadurch verdunckelt, Sondern Christus mit allen seinen wolthaten wird dadurch weggerissen Und das gantz Euangelium, wie S. Paulus hie zeuget, verkeret."

11 Karl Thieme, in his "Die Schädlichkeit der guten Werke bei Luther," Theologisches Literaturblatt 29 (1908), 41-42, identified a number of passages in which Luther discussed the detrimental nature of good works in justification but was unable to identify the source of Amsdorf's citation. So, too, was Dr. G. Koffmane in his editorial note on Amsdorf's introduction to Luther's sermons on John 18-20,WA 28, 766, note 1 . He suggested that the citation might have been an expansion of Lutcher's words on Galatians 1, 4, in his 1535 Galatians commentary, "Et mea iustitia mihi non prosit, sed plus obsit, ..." WA 40, I, 88, 29. The parallels between Amsdorf"s citation and the quotation from Luther given in note 12 are too positive to permit Koffmane's identification to stand.

12 Luther first spoke of those who teach "praeter fidem in Christum opera legis divinae necessaria esse ad salutem," WA 40, I, 112, 16-17; Luther's Works, Volume 26, Lectures on Galatians 1535, ed. Jaroslav Pelikan and Walter A. Hansen (St. Louis: Concordia, 1963), p. 52. Later he wrote, "Apparet autem res esse perexigua docere legem et opera statuere, Sed ea plus damni affert, quam humanus captus assequi potest. Nam non solum obscurat cognitionem gratiae, sed Christum cum omnibus suis beneficiis tollit et totum Evangelium, ut Paulus hic ait, evertit," WA 40, I, 115, 18-21; Luther's Works, 26, 54-55. The English translation above is taken from this volume. 
13 Most of the examples of Luther's expression of the concept of the detrimental nature of good works in regard to salvation, which I have found largely through the help of Thieme's article, come from the period in which Amsdorf was still a member of the Wittenberg faculty and in close contact with Luther:

"Nam nisi quis sit perfecte mortificatus, plus nocent ei virtutes et bona opera quam peccata," Sermon of November 30,1516, WA 1, 102, 20-21.

"...Apostolus plane negat esse nisi per fidem Iesu Christi, caetera omnia opera, etiam sacratissimae legis dei, adeo non praestare iusticiam, ut etiam peccata sint et hominem peiorem faciant coram deo, ..." Commentary on Paul's Epistle to the Galatians, 1519, WA 2, 503, 28-30.

"... non sunt necessaria, imo sunt noxia opera legis cuiuscunque Sed necessaria sunt et salubria opera bona quaecunque, ..." "Contra malignum I. Eccii iudicium M. Luthers defensio. 1519," $W A$ 2, 650, 1-8.

"Haec dicta sint de interiore homine, de eius libertate et de principe iustitia fidei, quae nec legibus nec operibus bonis indiget, quin noxia ei sunt, si quis per ea praesumit iustificari," "Tractatus de libertate christiana, 1520," WA 7, 59, 21-23; cf. the German, WA 7, 29, 31-34.

"Darumb sihistu, wie die gantze schrifft nur auff den glawben treybt und die werck furwirfft als untuchtig, ia, ergerlich und hynderlich zur rechtferttigung und solchem auffstehen," "Weihnachtspostille, 1522," Sermon for the Sunday after Christmas, WA 10, I, 1, $397,9-11$.

"... darumb schadett unnd hulfft mich das werck gar nichts. Alsso machen auch die werck des gesetzes niemant frum, ..." "Weihnachtspostille, 1522," Sermon for New Years Day, $W A$ 10, I, 1, 451, 21.

"unsere werck... sein uns schedlich zur selikeit und dem Reich Gottes," Sermon of October 24, 1522, WA 10, III, 373, 37 - 374, 2.

"...werck sein am schedlichsten zur seligkeit, ..." Sermon of October $26,1522, W A 10$, III, 387, 12-14.

"Haec est fiducia in operibus propriis, qua non est pestilentior pestis et adversaria fidei seu fiduciae in misericordia dei ... Nam haec est rapina gloriae dei," "Deuteronomion Mosi cum annotationibus," $1525, W A 14,634,32-35$.

"Darumb ist sie [die gerechtigkeit des Gesetzes] mir fur Gott nichts hülfflich, sondern mehr schedlich gewesen." "Crucigers Sommerpostille, 1544," Sermon for the twenty-third Sunday after Trinity, composed originally in 1536, WA 22, 364, 17-18; cf. lines 25-32.

14 Eyne christliche fur betrachtung So man wil bethen das heylige vater vnser Getzogen auss den predigetenn Doctoris Martini Luther zu wittemburg Von dem wirdigen Nicolao von Amssdorff (Leipzig: Stöckel, 1519), a tract in which Amsdorf put forth in his own words salient ideas he had gleaned from Luther's sermons on the Lord's Prayer. The text is found in WA 9, 223-25; p. 224, 4-7: "So kranck, so dorfftigk, so elendt, so verwunt bin ich Ja halb tot, das auch das gute werck, das ich thu, mir nicht gut ist, Sunder schedelich und verdamlich, $\mathrm{Du}$ wollest es dan allein auss deyner milden lautern barmhertigkeyt gar umb sunst an alle mein verdinst zu gnaden an nemen."

15 In his tract Das die Propositio (Gute werck sind zur Seligkeit schedlich) ein rechte ware Christliche Propositio sey durch die heiligen Paulum vnd Lutherum gelert vnd geprediget (Magdeburg, 1559), Amsdorf referred to his antagonist as "Master Klügel" or "Klügelings," punning on Hügel's name and the word "klug," lvs. (Aiv)r, Bij, Biijv.

16 Bekentnis D. Georgij Maioris von dem Artickel der Iustification das ist von der Lere das der Mensch allein durch Glauben on alle verdienst vmb des Herrn Christi willen vergebung der Sǘnden habe... (Wittenberg, 1558), If. Bijv. Major's confession was also issued in Latin.

17 CR IX, 406-07; cf. cols. $473 \mathrm{ff}$. and $496 \mathrm{ff}$.

18 See note 15 above for the title. Amsdorf also formulated his ideas in regard to his proposition in two pieces which remain in manuscript form, both in the Goethe-Schiller Archiv of the Nationale Forschungs- und Gedenkstätten der klassischen deutschen Literatur in Weimar, folio volume 39 and 40 of the collection of the Ehemalige Thüringische Landesbibliothek:

1. "Propositiones Nicolai Amsdorfij Contra nouas Maioristas," 40, 246r-251r;

2. "Widder die Maioristen so Georg Maiorem schützen vnd vertedigen," 39, 80r-89r; another copy, lvs. 58r-65r.

19 The attack on Major is found on If. C of Das die Propositio; on Hügel, see note 15. 
20 The suggestion was made by Otto Ritschl, Dogmengeschichte des Protestantismus (Leipzig: Hinrichs, 1908-1927), II, 414. Amsdorf had had a disagreement with Flacius and Wigand over the proposition, "good works are necessary theoretically in the doctrine of the law" (see Kolb, Amsdorf, pp. 145-55), but there is no indication that that disagreement played any role in the controversy over Amsdorf's proposition. On the contrary, Wigand defended it; see note 33 .

21 Das die Propositio, 1f. Aijr.

22 On Biel, see Heiko A. Oberman, The Harvest of Medieval Theology: Gabriel Biel and Late Medieval Nominalism (Grand Rapids: Eerdmans, 1967); pp. 131-45 in particular deal with his doctrine of salvation.

23 Das die Propositio, 1f. Bv.

24 "Contra Maioristas," 40, 246v.

25 Das die Propositio, lvs. (Aiv)v-Bijv. This view of works agrees with Luther's view and probably indicates no more than Amsdorf's dependence on Luther. However, it is one of the few possible indications of lingering Scotist influence on Amsdorf. He had received his earliest philosophical instruction from Scotists at Wittenberg. Few passages in his later writings give even a hint of possible Scotist influence, but Duns Scotus' concept that "nothing created must be accepted by God" could stand behind Amsdorf's view at this point. That concept stressed that God is free to accept or reject what he has made, including his human creatures, without any condition according to his absolute power; see Werner Dettloff, Die Lehre von der Acceptatio Divina bei Johannes Duns Scotus (Werl: Colde, 1954). Since Dettloff finds little remaining of this doctrine among late fifteenth century Scotists (see his Die Entwicklung der Akzeptations- und Verdienstlehrevon Duns Scotus bis Luther [Münster: Aschendorff, 1963]), it is impossible to determine to what extent the Scotist concept influenced Amsdorf and to what extent he was simply repeating Luther.

26 Das die Propositio, If. (Biv)v.

27 E.g., in "Tractatus de libertate christiana," WA 7, 62.

28 Das die Propositio, 1vs. (Aiv), (Biv). Amsdorf had acquired the illustration of the good tree which produces good fruit from Luther quite early; he used it in a disputation on good works in August 1522, the text of which is reproduced in Johann Erhard Kapp, Kleine Nachlese, (Leipzig: Braun, 1727), II, 553-54, and in many tracts thereafter.

$29 \mathrm{He}$ is sometimes labeled an antinomian for his proposition under consideration and for his criticism, along with Andreas Poach, of the proposition, "good works are necessary for salvation theoretically in the doctrine of the law." On the latter debate, see Kolb, Amsdorf, pp. 145-55. In both cases he never suggested that the law plays no role in the life of the Christian but was simply combatting any reliance on the works of the law in the process of justification.

30 Tertius Tomus Operum Reverendi Viri, D. Georgii Maioris, Continens Homelias in Evangelia Dominicalia \& dies Festos (Wittenberg: Lufft, 1570), If. 2r, in a preface dated Palm Sunday 1562. Earlier, in reply to the Wittenbergers' Scholasticorum Academiae Witebergensis... Epistolae, Amsdorf had prepared a tract which was never published, "Auff der Wittenbergische rott briff so sie wider die flatianer haben lassen aus gehen. Kurtze antwort," dated 1560, in manuscript in the Goethe-Schiller Archiv, Weimar, Ehemalige Thüringische Landesbibliothek volume 39, 244r-258v. Amsdorf replied in "Das Doctor Georg Maior in der vorrede vber seine new postill vns mit dreien lugen vnd einer grose Inurien beschwert vnd vnrecht thut," Goethe-Schiller Archiv, Weimar, Ehemalige Thüringische Landesbibliothek volume 39, 95v-97r.

31 Pflug, Christliche Ermanung an des Naumburgischen Stieffts Vnderthanen vnd vorwandten wie sie sich bey dem vorgefallenem hochbeschwerlichem missvorstand in Religions sachen halten sollen... (Cologne: Quentel and Colemius, 1562), lf. Riijv; Spangenberg, Wider die Vnchristliche Ermanung so Julius Pflug von Religions sachen an des Naumburgischen Stiffts Vnterthanen... hat ausgehen lassen. Gegenbericht vnd Warnung (Eisleben: Gaubisch, 1562), lvs. Dv-Dijr.

32 Wieder Niclaus von Ambsdorffen vngegründte schrifften, darinne er gute wergk anzeucht, Als seindt sie zur Seligkeit schedlich, vnd die Horas Canonicas vngestumer weyse verwirfft. Durch Christianum Lauterwein von Seligenstedt (n.p., 1562). The immediate cause of this 
attack lay in Amsdorf's Horas Canonicas Klostern vnd Stifften singen Vnd gebotene Adiaphora halten ist eben so wol Abgotterey Als die schentlichste Opffermesse (Jena: Thomas Rhebart, 1562). The author of the tract is not identified in Michael Holzmann and Hanns Bohatta, Deutsches Pseudonymen-Lexikon (Vienna, Leipzig, 1906; reprint, Hildesheim: Olms, 1961), where it is not mentioned at all, nor in Emil Weller, Lexicon Pseudonymorum (Regensburg, 1866; reprint, Hildesheim: Olms, 1963), where it is, p. 311 . Although any of several Philippists might have written it, the possibility that its author was Johannes Pfeffinger, professor of theology at the University of Leipzig until his death in 1573, comes quickly to mind. Pfeffinger had had a bitter - though brief - exchange with Amsdorf in 1558 and 1559 over Pfeffinger's views of the role of the will in conversion. Their dispute had ended rather abruptly (see Kolb, Amsdorf, pp. 188-201), and it is likely that Pfeffinger would have welcomed an opportunity to repudiate Amsdorf's position. If he had wanted to preserve his anonymity, it is likely that he would not have touched on the subject of his own recent quarrel with Amsdorf. The tract's concern with canonical hours could also point to Pfeffinger, who had been deeply involved in the Adiaphoristic controversy (a more remote source of his antagonism against Amsdorf), where canonical hours had been a minor issue; he certainly was interested in liturgical matters and was a close friend of Prince Georg von Anhalt, who is mentioned favourably in this tract, 1f. Dr. However, no conclusive evidence for Pfeffinger's authorship is to be found in the tract.

33 Weller criticized Major's and Amsdorf's propositions in the preface to his commentary on Ephesians, dated October 1, 1558, Opera Omnia (Divinae Doctrinae). Solidae Consolationis Plenissima I (Leipzig: Stock, 1702), 672-74. Wigand's reply remains in manuscript in the Herzog August Bibliothek in Wolfenbüttel and is quoted in Christian August Salig, Vollständige Historie der Augspurgischen Confession. . . (Halle: Renger, 1730-1733), III, 577.

34 On this controversy, which ranged Amsdorf against Wigand, among others, see Kolb,Amsdorf, p. 235.

35 The account of the colloquy published by the Wittenbergers is Gantze vnd Vnuerfelschete Acta vnd handlung des Colloquij zwischen den Churfurstlichen vnd Furstlichen zu Sachsen etc. Theologen (Wittenberg: Lufft, 1570); on Amsdorf's proposition, see for example lvs. $228 \mathrm{v}-230 \mathrm{r}$. Wigand and his colleagues issued a critique of this Wittenberg version, Bericht Vom Colloquio zu Altenburgk. Auf den endlichen Bericht etc. (Jena, 1570) and defended Amsdorf, see lvs. Eiiij and Ffr. The Jena faculty cited Luther (WA 2, 503, 28-30 and 40, I, 88, 28-30) in Amsdorf"s defense.

36 On this somewhat controversial identification of Chemnitz as a fellow traveller of the GnesioLutherans, see my sketch for an argument in "Parties, Princes, Pastors, and Peace, The Formulation of Concord, 1577," Academy, Lutherans in Profession, 34 (1977), 9-10.

37 "Kirchenordnung unser, von Gottes genaden Julii, herzogen zu Braunschweig und Lüneburg etc. 1569," Die evangelischen Kirchenordnungen des XVI. Jahrhunderts, ed. Emil Sehling VI, 1 (Tübingen: Mohr, 1955), 111. Chemnitz cited the Augsburg Confession articles VI and XX, 27-34, Bekenntnisschriften, pp. 60 and 80-81, Book of Concord, pp. 31-32, 45, and the Apology of the Augsburg Confession IV, 89, Bekenntnisschriften, p. 179, Book of Concord, p. 120.

38 Sechs Christlicher Predig Von den Spaltungen so sich zwischen den Theologen Augspurgischer Confession... erhaben (Tübingen: Gruppenbach, 1573), pp. 22-27; see my translation, Andreae and the Formula of Concord, Six Sermons on the Way to Lutheran Unity (St. Louis: Concordia, 1977), pp. 78-81.

39 Formula of Concord, Ep IV, 17-18; SD IV, 37-39; see note 1.

40 Lange, Ein Theologisch Bedencken von der newen Formula Concordiae (n.p., 1580), 1f. Cijr; cf. a similar expression in the anonymously edited Epistolae quaedam et Scripta. De conciliationibus Iacob Andricis (n.p., 1578). Spangenberg, Von der Weimarischen Predigte: so daselbst D. Jacob Andree, am 25. Sontag nach Trinitatis, Anno 1577. gethan. Bericht (n.p., 1578), 1f. J2, was attacking Andreae's Ein Christliche Predigt Vber das Euangelium auff den xxv. Sontag nach Trinitatis (Leipzig: Steinman, 1578), in which he rejected Amsdorf's proposition, lvs. Gv-Gijr. 